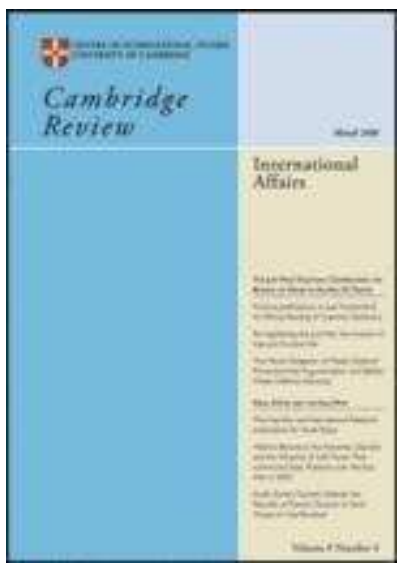

\title{
Uneven And Combined Development: A fusion of Marxism and Structural Realism
}

\begin{tabular}{|r|l|}
\hline Journal: & Cambridge Review of International Affairs \\
\hline Manuscript ID: & CCAM-2010-0016.R1 \\
\hline Manuscript Type: & Original Article \\
\hline Keywords: & Uneven and Combined Development, Marxism, Realism \\
\hline \multicolumn{2}{|}{} \\
\hline
\end{tabular}

SCHOLARONE ${ }^{m}$ Manuscripts

URL: http:/mc.manuscriptcentral.com/gieh Email: criacis@hermes.cam.ac.uk 


\title{
Uneven And Combined Development: A fusion of Marxism and Structural Realism
}

\begin{abstract}
Although Justin Rosenberg's academic writings have from the very beginning attempted to provide an alternative to Neorealism in the form of uneven and combined development, his attempts at actually replacing it with a general theory of his own is relatively recent. ${ }^{1}$ His initial attempts raised much interest and several responses. In his latest paper, Basic problems in the Theory of Uneven and Combined Development, part II: unevenness and political multiplicity, Rosenberg acknowledges that in actual fact, despite his attempts to provide an alternative to Neorealism, his own theory presupposed political multiplicity and therefore in his latest article he has sought to rectify this by providing an account of the emergence of the international - 'politically fragmented space' - one that is explicitly grounded in historical materialism. ${ }^{2}$ As such, it is to be welcomed. However, this paper argues that if we are to accept his theory of the emergence of multiplicity then it must provide a better explanation than other competing accounts. By using an alternative explanation of the rise of the international, this paper demonstrates that Rosenberg has failed to do this and as an alternative posits two trans-historical generative structures - societal stratification and the anarchical structure of the international. ${ }^{3}$ From these are derived the inextricable intertwining of the modes of production and inter-state competition. These provide the general tendencies of societal development which then need to be applied to the concrete circumstances of history. In so doing, the different analytical registers of genesis, structure, epoch and conjuncture and the unique concatenation of factors that pertain for each of these need to be accounted for. ${ }^{4}$
\end{abstract}

\section{Introduction}

Although Justin Rosenberg's academic writings have from the very beginning attempted to provide an alternative to Neorealism in the form of uneven and combined development, his attempts at actually replacing it with a general transhistorical account of human development is relatively recent. His efforts have thus far resulted in several key papers on the subject, which this paper divides into Rosenberg's Uneven and Combined Development Part I and II (RUCD I \& II). ${ }^{5}$ Although this division is somewhat arbitrary, it is warranted by the fact that in RUCD II he acknowledges that in his earlier work he treated the existence of multiplicity as a presupposition thus failing to provide an account of the emergence of the international itself - something which RUCD II seeks to rectify. 
Rosenberg's latest theory of the international is extremely ambitious and wideranging. In creating such a theory, Rosenberg seeks to satisfy three main objectives: to provide a better account of the international than those that posit two logics - the logic of territory and the logic of capital - as an explanation; to provide an alternative non-reified account of the international to that of Neorealism; and to furnish us with a grand narrative that explains the general patterns of social development throughout history.

This paper reviews Rosenberg's recent attempts to provide a trans-historical account of societal development that gives due recognition to the influence of the international. In so doing, it puts forward an alternative non-materialist account of the emergence of social multiplicity and the anarchical environment associated with this development. It then proceeds to provide an alternative approach that merges the key insights of both Marxism and Structural Realism. As such, it posits two trans-historical generative structures that account for the general evolution of societal development: social stratification and anarchy. From these two social structures, the inextricable intertwining of various modes of production and modes of inter-state competition are derived. Interpreting uneven and combined development as the complex interaction of these two modes then needs to be complemented by a detailed analysis of: the genesis and structural phases of the various modes of production/inter-state competition; a further breakdown into distinctive epochs during the lifetime of various modes of production; and, finally, a focus on determinate historical moments. ${ }^{6}$

\section{Marxist Approaches to Uneven and Combined Development}

The recent return by Marxists to the question of imperialism has prompted the greater incorporation of the dynamics of inter-state rivalry into their explanations. Their accounts indicate a greater appreciation that, at the international level, the anarchic realm in which a multiplicity of states resides does indeed generate a certain dynamic, but that this dynamic needs to be contextualized 'within the larger theory of the capitalist mode of production and of its historical development'. ${ }^{7}$ As a result, several have followed Giovanni Arrighi's move and argued that international politics is a complex interweaving of two logics; that of geo-political competition and that of the organic tendencies of capitalism. ${ }^{8}$ Alex Callinicos, for example, attempts to 'extend Marx's method in Capital of elaborating a theory of the capitalist mode as a whole by progressively and non-deductively, introducing ever more complex determinations to treat the state system itself as one such determination'. ${ }^{9}$ This method of progressive, non-deductive concretization, Callinicos argues, has the

URL: http:/mc.manuscriptcentral.com/2 /ieh Email: criacis@hermes.cam.ac.uk 
benefit of acknowledging that certain non-reducible properties pertain to the international level while at the same time integrating 'all the relevant empirical content in an articulated structure' ${ }^{\prime}{ }^{10}$

For Callincos, in order to fully understand the relations, processes and contradictions inherent within the capitalist system it is essential to include interstate relations and the domestic/international dynamics that derive from the complex melding with the 'vertical' and 'horizontal' capitalist relations of production ${ }^{11}$ The market driven 'horizontal' competitive process between individual capitals, from which the organic tendencies of capitalism derive, not only increasingly exacerbates the 'vertical' antagonism between classes as a result both of the quotidian accumulation process and the periods of over accumulation/crisis that this horizontal competition gives rise to, but also has important consequences for inter-state relations. National networks of capital with interests far beyond the borders of the state within which they reside led to the eventual subordination 'to their interests the system of sovereign territorial states that had developed out of the process of 'political accumulation' (warfare and state building) that dominated Europe in the later Middle Ages and the early modern era'. ${ }^{12}$ As a result a fusing of the 'logic of territory' and 'logic of capital' occurs, in which the 'resulting interrelations between capitalist economic networks that remain nationally constituted even if their reach may be global and specific nation states are complex, changing and irreducible to any simple instrumentalising of one party by another' ${ }^{13}$

For Rosenberg, however, the problem with such a formulation is that it fails to explain the actual fact of the international. Rather than explaining the existence of the multiplicity of states, Callinicos (and other Marxists) take this as a given and then proceed to explain both the essential social configuration within states in any given historical epoch and, at the same time, the particular form that interstate relations take in relation to the dominant mode of production pertaining to this period. Rosenberg thus believes that Callinicos' attempts at including the international within a Marxist analysis of history has replicated the error of previous Marxist accounts of focusing on 'how the social character of this multiplicity (and of its causal mechanisms) has in fact varied crucially according to historical changes in the dominant mode of production' and not on the 'transhistorical fact of geopolitical multiplicity' itself. ${ }^{14}$ As such, it constitutes a second-image explanation of the international accounting for 'the sociohistorical form of multiplicity ... but not the fact of it' ${ }^{15}$ 
Rosenberg not only wants to provide a better historical materialist account of the international than the above, his objective is also to avoid the reification of the international by treating the multiplicity of states, a là Neorealism, as a social fact in itself and as an 'independent source of causality' ${ }^{16}$ In attempting to do so, he makes an analogy with Marx's analysis of value in volume one of Capital in which Marx unmasks the deeper social relations that lie behind commodity exchange. As Rosenberg points out, Marx aims to reveal the inverted and reified form that commodity exchange has assumed. ${ }^{17}$ The surface level of commodity exchange gives an appearance of a relationship between things whose value seems to emanate from the nature of the products themselves. The real social relation between producers is thus disguised through the mediation of the market and the monetized form that exchange takes, which 'conceals the social character of private labour and the social relations between the individual workers, by making those relations appear as relations between material objects'. ${ }^{18}$ This process of objectification hides the true basis of exchange values, which is not some innate material quality associated with the product itself but rather it is the amount of 'congealed labour-time' (or more accurately, the 'labour-time socially necessary for its production') embodied within a commodity relative to other commodities. ${ }^{19}$ But this 'determination of the magnitude of value by labour-time'...is...'a secret hidden under the apparent movements in the relative values of commodities. Its discovery destroys the semblance of the merely accidental determination of the magnitude of the value of the products of labour' ${ }^{20}$

In a similar fashion, Rosenberg seeks to unravel the reified form of geopolitical competition devoid of any generative sociological processes that Neorealism presents to us. He does so by situating geopolitics within a process of uneven and combined development which is posited as a 'sociological characteristic of all historical development...entailing, as it does, an inner differentiation and interactivity to the historical process'.$^{21}$ By viewing societal development as both uneven and combined ensures that we don't fall into the trap of treating societies as ontological singularities, shifting the focus toward multiplicity, interactivity and multilinearity. Historical development is thus a constantly evolving cumulative product arising from a complex of interactions between endogenous and exogenous processes. Geopolitics is no longer viewed as an autonomous sphere of interaction but rather derives from the fact that all societies 'confront the fact that the human world extends beyond themselves, and that the resultant imperative to manage the "outside" world, if only minimally for reasons of survival, compels them into interaction with each other' ${ }^{22}$ Such interaction is

URL: http:/mc.manuscriptcentral.com/gieh Email: criacis@hermes.cam.ac.uk 
said to "super-add(s) a lateral field of causality over and above the "domestic" determinations arising from each and every one of the participant societies' ${ }^{23}$

\section{Rosenberg's Version of Uneven and Combined Development}

In order to achieve these objectives Rosenberg employs Trotsky's theory of uneven and combined development originally used to explain why Russia had failed to follow the unilinear path of capitalist development predicted by Marx and Engels. The explanation, of course, lay in the very fact that capitalism had already occurred elsewhere. As a result the revolutionary effects of this mode of production in virgin territory would not mirror that of the original 'capitalist pathfinder'. ${ }^{24}$ Driven by the 'whip of external necessity' states desperately seek to catch up with the lead states lest their relative decline should end in their demise. Yet, in tandem with this imperative that states find impossible to ignore, comes the opportunity to use the 'privilege of historic backwardness' to catch up through the adoption of contemporaneous technologies thus 'skipping a whole series of intermediate stages' ${ }^{25}$

Moreover, the birth pangs are somewhat unique for each case: the very fact that capitalist development does not occur in isolation means that in each country 'a peculiar combination of different stages in the historic process'...emerge, so that...'Their development as a whole acquires a planless, complex, combined character' ${ }^{26}$ As capitalism reaches out beyond its original borders an unstable fusing of old and new occurs; not only do unique amalgams of different modes of production arise but even more interesting combinations of class alignments occur. ${ }^{27}$ In other words, this geographical expansion ruptures the ossified structures of these societies not along some unilinear and predictable path, but in such a manner that classes associated with a previous historical epoch not only subsist but actually act as the midwives of capitalism within their state - 'Unable to avoid the imperative of industrialization, but unwilling to dissolve the (noncapitalist) basis of their own rule, they mobilized the power of the state to combine the one with the other, generating in each case an unstable sociological "amalgam"'.28

Rosenberg's initial work in this area focused on encompassing geopolitical competition in the wider context of socio-economic development. In so doing, the geopolitical is no longer viewed as subsisting autonomously with the causal dynamics of power competition emanating from the anarchic realm of the international - treated as an isolatable social fact, separate from the wide ranging and complex array of socio-economic dynamics occurring within and between 
societies. Rather, geopolitics is seen as an integral aspect of the uneven and combined developmental process.

But in order for uneven and combined development to explain these dynamics it has to be temporally extended beyond its original context of capitalism to include the variety of socio-economic formations that came before this particular mode of production. Development is still posited 'ontologically as the subject matter of the analysis, it identifies the evolution of social structures in historical time as the basis of its explanatory method'. ${ }^{29}$ But, unevenness is now viewed as a general transhistorical characteristic of development as a result of the varied pace of evolution amongst societies. Combined development is also shorn of its original meaning. Trotsky was referring to the extension of capitalist relations from the vanguard state outward to those societies still operating under earlier modes of production and the manner in which this revolutionary socio-economic form impinged upon earlier social forms generating unique fusions of social structures. As others have already pointed out, in Rosenberg's earlier writings (RUCD Part I), combined development takes on several meanings: the 'coexistence and interactive development of all societies throughout history'; ' an interdependence of "the structures of material and cultural life"; and, finally the process so well articulated by Trotsky, the melding of capitalism with various preceding modes of production to produce unique socio-economic structures. ${ }^{30}$

In his initial works, Rosenberg contended that this temporally extended version of uneven and combined development could supersede the neorealist explanation of geopolitics, asserting that the "very existence of "geopolitics", its imputed transhistorical "logics" and its varying forms and causal weight can all be explained via a generative sociological presupposition - the first two by reasoning from the general abstraction of "uneven and combined development" and the third by developing concrete abstractions of the latter's particular historical configurations'. ${ }^{31}$ But Trotsky's version of uneven and combined development actually presupposed both the multiplicity of the international and the geopolitical competition that exists in this anarchic environment. The "whip of external necessity' was none other than the geopolitical competition between states that derives from the imperative to survive in an anarchic international environment. ${ }^{32}$ As others have pointed out, 'The transformative impact of geopolitical competition on the internal constitution of societies was a theme running throughout Trotsky's work' ${ }^{33}$ Rosenberg's initial version of uneven and combined development did nothing to fundamentally alter this element of Trotsky's theory. Trotsky's version of uneven and combined development provided the potential for an excellent trans-historical account of the mechanism

URL: http:/mc.manuscriptcentral.com/gieh Email: criacis@hermes.cam.ac.uk 
through which shifting balances of power occur between states. Moreover, it focused our attention on the variety and complexity of amalgams of modes of production particularly during transitions from one historical epoch to another and the concomitant combination of class alliances that emerge as a result of this process. What it did not explain is the multiplicity of the international itself and the security dilemma between states that is said to attend this multiplicity. ${ }^{34}$

In order to provide a trans-historical account of the evolution of society that rivals Neorealism, Rosenberg in RUCD Part I presents a temporally extended version of Trotsky's uneven and combined development. In so doing, Rosenberg avoids the pitfall of other sociological approaches of treating societies as if they were ontological singularities. Instead, the focus is on 'social development conceptualized as a differentiated but nonetheless ontological whole'. ${ }^{35}$ Yet, his earlier version of the theory fails to actually explain multiplicity itself and the security dilemma that is said to obtain as a result. In his most recent paper RUCD Part II), Rosenberg attempts to rectify this weakness, the details of which are given below.

\section{Rosenberg's Uneven and Combined Development Part II}

Rosenberg's second attempt at explaining the multiplicity of the international using uneven and combined development sees the application of his approach applied to the late pre-historic period. Part II of RUCD rectifies his original application of uneven and combined development which pre-supposed the existence of multiplicity and had thus led to a theoretical impasse wherein his work provided an improved account of geopolitical balancing but was inherently incapable of explaining the emergence of the international itself. In so doing, he makes a crucial distinction between social multiplicity (two or more initially nonhierarchical groups) and political multiplicity (vertical social differentiation within units). The former is said to antecede the latter. This represents a critically important move by Rosenberg because it then allows him to argue that uneven and combined development preceded the 'political' (i.e. hierarchical social groups). Indeed, more than this, uneven and combined development explains the emergence of political multiplicity itself.

In this account, the late pre-historical period is marked by the evolution from hunter gatherer societies to sedentary ones - from a pre-international system to an international one. But prior to this change, Rosenberg contends, the social world constituted by these hunter gatherer bands (HGBs) was highly uneven as a result of geographical variation and the adaptive strategies adopted by these 
groups alongside evolutionary variation with groups acquiring certain capacities - 'such as language, control of fire, invention of clothing and artificial shelter' at different times. ${ }^{36}$ In addition, he contends that these societies were also 'combined' through the necessity of exogamous biological reproduction. These 'extending networks of consanguinity' are said to have 'provided the basis for periodic gatherings, shared language and security against environmental stress' $^{\prime 37}$

However, a radical rupture occurred in this social fabric with the arrival of sedentary agricultural groups and their ability to produce and preserve a surplus for use during less fertile periods. This change in productive capacity is said to have heralded the social consolidation of these groups and a sharpening of intersocietal divisions. It stimulated a shift in emphasis where the focus was more on the protection of the surplus from other groups and less on the need for exogamous links for biological reproduction (given that group size had grown with surplus production capability). The logic of security is said to change 'from dispersal to nucleation' as a result of the rise of self-reproducing, self-sustaining groups that need to protect their surplus in order to survive.

Most importantly for Rosenberg's thesis is that this change in productive capacity heralded the rise of political multiplicity. It is argued that some of the surplus could now be exchanged for 'durable luxuries' and the differential access to such goods 'plays an important role in...[the]...consolidation of internal hierarchy'. ${ }^{38}$ Authority within these embryonic sedentary groups issues from access to these 'prestige goods' which in turn are acquired from outside through the exchange of accumulated surplus, thus, 'external trade facilitates hierarchy,; and hierarchy, by generating "a constant need for new and exclusive prestige goods" promotes trade'.$^{39}$ For Rosenberg, the very origins of political entities are thus associated with the interaction (via the trading of goods) of the various social entities that pertained at the time. Uneven and combined development is therefore inextricably linked to the rise of political multiplicity as the combination of the logic of security and economic interaction of these societies leads to a 'hardening inside/outside division...[that]... necessarily congeals into finite entities'. ${ }^{40}$

\section{Basic Problems of Rosenberg's Uneven and Combined Development Part II}

Rosenberg's approach stands out for giving due recognition to the prolonged influence that the international anarchical structure has had throughout history. Rosenberg's endeavours to both produce a more generalized version of Trotsky's

URL: http:/mc.manuscriptcentral.com/gieh Email: criacis@hermes.cam.ac.uk 
uneven and combined development and integrate into this the geopolitical dynamics of inter-state competition are to be lauded. However, the costs incurred in so doing may be unacceptably high in relation to its productiveness and/or introduce internal inconsistencies such that the theory itself is debased. As has been pointed out previously by others, in Rosenberg's earlier writings, combined development takes on several meanings: the 'coexistence and interactive development of all societies throughout history'; 'an interdependence of "the structures of material and cultural life"; and, finally the 'combination' of capitalism with various preceding modes of production to produce unique socioeconomic structures. ${ }^{41}$ As others have pointed out, Trotsky's use of the term 'combination' is quite specific and should be differentiated from the more general term 'articulation'. Rather than simply denoting an interconnection between various modes of production, combination, should be regarded as 'a particular subset of articulation in which one of the modes ... impels the simultaneous transformation and reconstitution of the other'. ${ }^{42}$ But in RUCD Part II, this latter aspect completely drops out and, if interdependence is present at all, it is in an extremely weak form. This then raises the question whether Rosenberg has arrogated the term 'uneven and combined development' for a theory that bears little or no resemblance to the original.

Indeed, given the even greater level of generalization in RUCD II, with regard to Rosenberg's version of uneven and combined development, a more appropriate nomenclature would be 'varied and interactive development'. His account of the late pre-historic period hinges upon a comparison of societies marked by the presence and absence of certain geographical and/or evolutionary features. This variation bears no resemblance to Trotsky's concept of uneven development in terms of progressive modes of production. The tension is quite clear throughout the paper with Rosenberg often using the two terms - variation and unevenness interchangeably. Similarly, the term combination, which for Trotsky denoted the unique amalgams of socioeconomic structures arising from the global expansion of capitalism, in RUCD Part II refers to simple exchange between pre-historic societies.

Such dilution of terms is also apparent in Rosenberg's definition of development, based as it is on one of Marx and Engels' more general outlines of development in The German Ideology which explains the two way process whereby human beings shape nature in order to satisfy their needs and wants and in appropriating and transforming nature the 'species being' is also transformed, there is therefore 'a constant interaction between subject and object' such that human nature 'itself is the ever-changing product of human activity, i.e. of 
history' ${ }^{43}$ Because production is a social activity involving the cooperation of human beings, the production of the means of subsistence becomes a dual relationship - 'on the one hand as a natural, and on the other as a social relationship'44. This implies that certain methods of producing material needs will require certain types of cooperation between the individuals of the community concerned. At any particular stage in the history of a community these forces of production (means of production i.e. raw materials and instruments of production combined with labour power) will have reached a particular level and will require a corresponding division of labour within that community. ${ }^{45}$ It is then rather simple to construct a highly abstract generalization concerning the interaction of societies with different forms and levels of productive capacity - uneven and combined development.

However, the Preface To A Contribution To The Critique of Political Economy gives the more detailed and oft-cited specification 'In the social production of their existence, men enter into definite, necessary relations, which are independent of their will, namely, relations of production corresponding to a determinate stage of development of their material forces of production. The totality of these relations of production constitutes the economic structure of society, the real foundation on which there arises a legal and political superstructure and to which there correspond definite forms of social consciousness. ${ }^{46}$ If Rosenberg had used this more detailed version of development, it would at least provide us with falsifiable statements on which to assess the validity of his theoretical claims.

In fact, there are several interpretations concerning this and other passages: the technological thesis, the mixed mode thesis; and the political thesis. The controversy centres on what should be taken as the primary determining influence on history, the agency that provides the overall explanation for historical change in social relations. What comprises the totality of relations of production is not altogether clear from the passage and neither is the precise meaning of 'corresponding', hence the various interpretations of historical materialism.

The technological interpretation of historical materialism proposes that the forces of production explain why particular relations in society pertain at any particular moment in time - 'The primary thesis is that the nature of a set of production relations is explained by the level of development of the productive forces embraced by it (to a far greater extent than vice versa) ${ }^{\prime} .{ }^{47}$ Where relations of production refer to both a division of labour and the ownership of the means of production (defined as the instruments of production and the raw materials 
requiring transformation). This interpretation lends itself to a functionalist account of Marxism in which a set of production relations are said to obtain 'because they suit the development of the [production] forces' ${ }^{48}$ The mixed mode approach views both the forces and relations of production as constituting the economic structure of society that pertains in any given epoch. Human agency is viewed as a major determinant of socio-economic change, but new social formations will be enabled and/or constrained by the productive capacities that pertain at that any given point in time. In other words, the 'relation of correspondence between forces and relations of production do not involve the causal primacy of either term but rather their mutual presuppositions'. ${ }^{49}$ Alternatively, other Marxists argue for the primacy of relations of production (classes) as the driving force in history. ${ }^{50}$ Given these various interpretations, this paper will generally refer to the mode of production without differentiating between them (excluding the primacy of productive forces which very few now adhere to), because the emphasis here is on the possible fusion of Structural Realism and Marxism - regardless of which variant is chosen.

By employing a rather nebulous definition of development, Rosenberg has avoided many of the debates concerning exactly how societies actually do develop, particularly with regard to transitions from one mode of production to another. There may well be both endogenous and exogenous processes occurring that generate social and economic change, but what weighting should be given to one compared to the other is a far more difficult question. For example, in relation to feudalism, the debate continues as to whether the transition to capitalism was internally generated as a result of a change in the internal configuration of social forces as a result of class struggle that shook 'loose the small producer from feudal exploitation' and that "from the petty mode of production (in the degree to which it secures independence of action, and social differentiation in turn develops within it) that capitalism is born'. ${ }^{51}$ Or was it essentially a top down process where, as a result of the limited success of English peasant rebellion and their 'failure to establish essentially freehold control over the land, the landlords were able to engross, consolidate and enclose, to create large farms and to lease them to capitalist tenants who could afford to make capital investments' ${ }^{52}$ Was it instead long-distance trade acting as a 'creative force, bringing into existence a system of production for exchange alongside the old feudal system of production for use'...which...'naturally began to act upon each other'? ${ }^{53}$ Or was it, indeed, the result of a technological developments utilized by 'small groups of farmers, manufacturers in the city and some merchants, who began to exploit labour in a new way'...which 'occurs within feudalism, but in contradiction to feudalism'. ${ }^{54}$ Without explicating further 
precisely what is meant by uneven and combined development and moving from such a highly abstract schema to concrete analyses of historical change, the charge leveled at UCD that its 'suggestiveness is equaled only by \{its\} elusiveness' may have been an unfair charge to lay at Trotsky's door, but unless further specification is given, RUCD is in danger of fitting the bill..$^{55}$

As Perry Anderson reminds us, there are two distinct phenomena that Marx investigates: the genesis of a mode of production; and the structure of a mode of production. ${ }^{56}$ For example, the generative processes, such as primitive accumulation, may be necessary for the emergence of a mode of production, such as capitalism, but not necessarily for its continuance. ${ }^{57}$ Moreover, it is entirely possible that the same articulated structure may come into existence by a number of different "paths". The constitutive elements which compose it can be released in variant ways and sequences, from previous modes of production, before interlocking to form a coherent and self-reproducing system as such'. ${ }^{58}$ Trotsky's analysis focuses on the latter structural phase and, in particular, the inherent tendency of capitalism to expand in search of new avenues for investment for the expansion of production and new consumer markets for the absorption of the goods produced which would eventually lead to every corner of the world being affected by this revolutionary mode of production. These tendencies assume a hypertrophied form during crisis periods of overaccumulation, at which point capitalists desperately seek spatio-temporal fixes for their accumulated surpluses leading to, amongst other things, intense development of productive capacity and consumer markets in hitherto relatively less integrated regions. ${ }^{59}$ Trotsky's contribution was not to challenge those tendencies of capitalism that Marx had identified, but to indicate how the spillover of capital had dramatically different effects depending upon the socioeconomic structure of the society in question. But in addition, he also incorporated the geopolitical logic of necessity that impels states to catch up with other states lest they decline and possibly even fade away. State elites were thus viewed as opening up to capitalism in order to harness the accumulative capacity of capitalism for their own ends. The 'logic' of capital accumulation in unison with the 'logic' of geopolitics explained the patterns of uneven and combined development that Trotsky so perceptively observed. There are thus two avenues open to researchers wishing to deploy the insights of Trotsky's theory of uneven and combined development: the genesis and structure of a particular mode of production. Of course, this is in terms of research focus, but would eventually lead to the combination of the two to fully explain the emergence and maintenance of a given historical epoch. 
In relation to the generative phase, UCD can be deployed to explain the embryonic emergence of new modes of production and the political-legal superstructure that subsequently evolves. In order to do this, it needs to engage in the debates surrounding such transitional phases, clearly identifying the key constitutive elements of the transformative process. Moreover, it needs to prove that the unevenness and combined nature of development is actually a significant factor during such phases. That development is uneven and combined is not in dispute, but to avoid descent into facile truisms the research needs to demonstrate whether or not it is a significant factor for the emergence of the new mode of production and, if so, to what degree. The second approach would be to examine the structural phase of the embryonic mode of production, identifying its constitutive elements and how these are then combined with older modes of production across space as a result of the uneven nature of development. Under Rosenberg's schema, this may be in terms of simply interacting and affecting other societies without fundamentally altering their modes of production or it may lead to the emergence of unique amalgams of new and old modes heralding unique political-legal superstructures that emerge from these fusions. In other words, Rosenberg, a là Trotsky, needs to analyse the fundamental characteristics of the new socio-economic form that occurred in place $\mathrm{A}$ at time $\mathrm{T} 1$ and how this impacted upon places B, C, D... at time T2, T3, T4...

Rosenberg thus needs to further differentiate (and this may be his next development) between the transformative and structural phases of any given mode of production. He has also been criticized for an approach that involves a general theory of societal development at one end and detailed conjunctural analysis at the other. ${ }^{60}$ As Callinicos points out, it therefore 'occludes the specification of a level of conceptualization intermediate between the two' - the distinctive phases (epochs) during the lifetime of a mode of production. According to Callinicos, he uses 'a too undifferentiated concept of the conjunctural...developments, shifts, alterations which, however dramatic or extensive they may be, nonetheless remain changes within the existing historical form of society rather marking a fundamental "epochal" transformation in the nature of that society itself'. In other words, any change that leaves the mode of production in place is the proper object of conjunctural analysis. This fails to distinguish between two kinds of intermediary analysis that, while of a higher resolution than general theorizing about the capitalist mode, operate at different levels, respectively, that of a specific phase of capitalist development and that of a determinate historical moment - in other words, of epoch and conjuncture ${ }^{61}$. In order to further develop his theory, several extra levels of analysis are thus required to provide a full understanding of the historical process: the 
transformative and structural phases of any given mode of production; distinctive phases (epochs) during the lifetime of a mode of production; and, finally, conjunctural analysis that identifies a 'determinate historical moment' ${ }^{62}$

In addition, Rosenberg needs to add a further constitutive element to the process of combined development. Historical analysis indicates that modes of production contain within them 'a remanence of the legacy of one mode of production with an epoch dominated by another, and a reactivation of its spell in the passage to a third...the concatenation of the ancient and feudal modes of production are necessary to yield the capitalist mode of production in Europe...the actual movement of history is never a simple change-over from one pure mode of production to another: it is always composed of a complex series of social formations in which a number of modes of production are enmeshed together, under the dominance of one of them' ${ }^{63}$ We thus have an even more complex form of analysis where the researcher is not only required to identify the interaction between endogenous and exogenous processes, but also needs to identify certain remnant elements of much earlier modes of production whose significance resurfaces during the genesis of a new phase of development - le mort saisit le vif. ${ }^{64}$

\section{RUCD and the Realist Moment}

Can Rosenberg's theory of uneven and combined development successfully integrate an explanation of the geopolitical into a more general account of the socio-economic development of human society while providing a trans-historical account of social change? With RUCD Part II, Rosenberg's thesis is that a change in productive capacity heralded the rise of political multiplicity. However, one could equally argue that a realist moment occurred prior to this accumulation of surplus. Indeed, Rosenberg himself acknowledges that 'Archaeological evidence suggests that human settlement first occurred only sporadically, in places where natural abundance allowed for year-round foraging subsistence'.$^{65}$ It is equally plausible that consolidation of social groups began in these areas - the land was fertile enough to support settlement and eventually population growth which extirpated ${ }^{66}$ the need for exogamous social relations. ${ }^{67}$ Associated with this process was the need to protect the fertile territory that enabled this expansion of the social group. This, combined with the fact that 'Sedentary units are much more vulnerable to attack than mobile units', led to an increased emphasis concerning group security. ${ }^{68}$ In the absence of any provision of protection from a higher body and/or inter-group agreement, an anarchical environment developed - one in which the logic of security was that of self-help. 
In other words, one can argue that the 'anarchic moment' occurred prior to the production of surplus. Indeed, there is evidence that at the end of the first stage of global colonization that significant cultural change occurred, such as, 'burying their dead and looking after the sick and the old'. ${ }^{69}$ The settling on fertile plains may have acted as a further catalyst for this process of ethno-genesis, group identity formation and the 'hardening of inside/outside' divisions possibly combined with the rise of exclusionary 'identity politics'. If one accepts this sequence of events, then the emergence of anarchy is not dependent upon the accrual of surplus but by the inversion of social relations - the move away from exogamy to endogamy and some limited form of ethnogenesis. ${ }^{70} \mathrm{~A}$ disjuncture occurs in the process of uneven and combined development wherein the intersocietal relations which were marked by reproductive interdependency were slowly replaced by a developing anarchic environment of self-reproducing survival units.

It is striking that Rosenberg uses several passages from the German Ideology, yet he fails to refer to the Formen section of the Grundrisse which concentrates on early/pre-historical forms. This section bears a close resemblance to Rosenberg's outline of societal formation but differs in highly significant ways. Indeed, much of Rosenberg's thesis is implicit in Marx's explanation, but the chronology gives more support to the above brief sketch than it does to RUCD Part II. First, the initial mode of life chimes with Rosenberg's description of small migratory groups and Marx then adds that 'except possibly in a natural environment so especially fertile that they sit like monkeys on a tree'.$^{71}$ But one can also find support in Marx's writings for the separation of the embryonic growth of societies and the growth in productive capacities. Marx argues that the formation of the first communities arise from influences other than production - 'the natural community, appears not as a result of, but as a presupposition for the communal appropriation and utilization of land...This naturally arisen clan community, or, if one will, pastoral society, is the first presupposition - the communality of blood, language, customs - for the appropriation of the objective conditions of their life, and of their life's reproducing and objectifying activity...The real appropriation through the labour process happens under these presuppositions, which are not themselves the product of labour, but appear as its natural or divine presuppositions' ${ }^{72}$ Further on in the Grundrisse, Marx adds that 'The only barrier which the community can encounter in relating to the natural conditions of production - the earth - as to its own property (if we jump ahead to the settled peoples) is another community, which already claims it as its own organic body. Warfare is therefore one of the earliest occupations of each of 
these naturally arisen communities, both for the defence of their property and for obtaining new property'.$^{73}$

Moreover, reflecting on the initial establishment of Rome, Marx argues that 'The aim of all these communities is survival; i.e. reproduction of the individuals who comprise it as proprietors'. The survival imperative inherent in these communities perforce drives them toward 'new production and destruction of the old form...[where]... the advance of population is already under way. If this is to be corrected, then colonization, and that in turn requires wars of conquest. With that, slaves etc. Also, e.g., enlargement of the ager publicus, and therewith the patricians who represent the community etc. ${ }^{74}$

One could thus argue that an anarchical structure arises from the inversion of social relations earlier identified. This inside/outside relation is then exacerbated by the 'unresolvable uncertainty' of intentions that exists in the absence of a higher authority. ${ }^{75}$ Such a situation would satisfy the two conditions that Waltz identifies as necessary for inter-societal competition (geopolitics) to pertain 'that the order be anarchic and that it be populated by units wishing to survive' ${ }^{76}$ Such an interpretation still meets Rosenberg's objective of conceptualizing social development as a differential but nonetheless ontological whole. The shift from exogamy to endogamy, self-reproducing and self-sufficient groups leads to social change that involves both deeper differentiation and the emergence of an anarchical structure which paradoxically binds these societies in a competitive community of fate.

However, initially the degree of interaction would have obviously varied both inter-regionally and intra-regionally. Following the arguments laid out in The Logic of Anarchy, such conditions would not at first be satisfied system-wide, but would initially emerge as various localized sub-systems in which 'adjacency compensates for low levels of interaction capability' ${ }^{77}$ The degree of interaction within sub-systems would be significantly higher than that between sub-systems. But eventually, increases in interaction capacity (the 'absolute quality of technological and societal capabilities across the system') and sub-system expansion would lead to the emergence of one unified system. ${ }^{78}$ In relation to the latter sections of this paper, this systemic interaction capacity is clearly related to what Michael Mann refers to as the 'infrastructural power' power of the states within the system, and this in itself will reflect the level of productive forces at that point. ${ }^{79}$ Moreover, such systemic societal capabilities will reflect the relations of production and the degree to which surplus accumulation relies on extraeconomic coercion. ${ }^{80}$

URL: http:/mc.manuscriptcentral.com/gieh Email: criacis@hermes.cam.ac.uk 
If such is the case, then a competitive inter-societal dynamic can be explained without initial reference to the revolutionary effects of surplus accumulation and precedes the emergence of the succeeding social stratification that Rosenberg describes. Indeed, one could argue that the initial stratification of these societies resulted from the emergence of a division of labour based upon protection whereby leadership was no longer based on authority but power as a result of their new ability to 'coerce their followers'. ${ }^{81}$ For Rosenberg, the sequence of events is as follows: initial social existence of HGBs; settlement on fertile territories; production of surplus; logic of security evolves from dispersal to nucleation and emergence of social multiplicity; trade in surplus and need to protect surplus; social differentiation arising from accumulation of wealth spurred on by exchange in prestige goods; congealing of inside/outside division; mimetic moment the initiation of the emulative process and the emergence of political multiplicity.

In so doing, Rosenberg associates the emergence of the international with the emergence of political multiplicity. However, the main characteristics of the international are that it is an anarchic environment within which units seeking to survive reside. What we then have is the following sequence. The existence of multiplicity in the form of hunter gatherer bands; some of these settle on highly fertile land; immobility leads to greater vulnerability and the survival imperative leads to the protection of territory from those outside of the group; the growth in the size of the group (that these fertile areas permit) plus the increased vulnerability leads to nucleation and the emergence of social multiplicity (i.e. groups reliant on endogamy more than exogamy); the emergence of the realist moment - the security seeking behaviour by one group is replicated through-out various sub-systems, i.e. the mimetic moment, initiation of the emulative process, and eventually, once interaction capacity reaches the required level, between sub-systems creating an international anarchical structure; surplus accumulation begins possibly spurred on by territorialisation (ability to store and protect surplus); differential access to surplus arising from the division of labour; differentiation exacerbated by the trade in prestige goods.

Thus one can postulate that inter-group rivalry emerged as a result of the need to secure fertile territory which in itself had allowed for population growth to a level which eradicated the need for 'continuous symbiosis with neighbours' ${ }^{82}$ This social nucleation concomitant with settlement leads to the congealing of inside/outside social divisions and the emulation of this process by others leading to the emergence of the 'international' i.e. an anarchic environment 
populated by units seeking to survive. In other words, a realist moment antecedes the surplus accumulation moment. Inter-unit competition/conflict would then be exacerbated by the accumulation of surplus.

Rosenberg's work is to be lauded for its analytical rigor and appreciation of the importance of the international anarchical structure, yet this paper questions his attempt to produce an historical materialist account of its origins. In what follows, this paper seeks to retain these insights concerning the trans-historical nature of anarchy and the inextricable intertwining of the domestic and international. But a distinction needs to be made between: the deep structure of anarchy (the absence of a higher authority and an environment populated by units seeking to survive); the inter-unit competition that this fosters (leading to external stratification in terms of degrees of relative power capabilities); and internal stratification (in terms of the distribution of surplus extraction, reflecting the relations of production).

\section{A Fusion of Marxism and Realism}

The objectives and methods of Neorealism and Marxism differ to such an extent that any attempt at fusing the two would appear to be futile. For Waltz, a theory must be both parsimonious and non-reductionist. To this end, he is seeking an abstract theory of international reality, which, although it may only be a simplification of that reality, can nevertheless still explain and predict state behaviour. The intention of such an abstraction is to illuminate and clarify the major causes of state behaviour at the international level:

The theoretical strategy is to make the fewest assumptions possible and use the smallest imaginable number of explanatory variables. Structural realists self-consciously sacrifice richness and depth for a simple, rigorous theory that holds widely across time and space. ${ }^{83}$

Waltz's theory is thus intentionally bereft of any detailed analysis of the domestic characteristics of states, such as culture, ideology, and political institutions. These characteristics are only considered in terms of how they enhance or diminish the power of the state in the international arena (but state behaviour in general will be unaffected in the long term). Waltz is fully aware that providing an account of the constitutions and processes within states will bring us closer to social reality, but this would involve a 'move away from a theory claiming explanatory power to a less theoretical system promising greater descriptive accuracy'. ${ }^{84}$

URL: http:/mc.manuscriptcentral.com/gieh Email: criacis@hermes.cam.ac.uk 
Waltz's version of Neorealism informs us of two major recurrences: first, that, 'international politics reflects the distribution of national capabilities, a proposition daily borne out'; and second, that, 'the balancing of power by some states against others recurs. Realist theory predicts that balances disrupted will one day be restored' ${ }^{85}$ Viewed from this perspective, much criticism directed at Neorealism is misplaced because it has assumed too much of the theory. As Waltz has elsewhere stated, as both an explanatory and predictive theory, Neorealism is extremely limited in what it can and cannot predict; but what it can do is, 'explain certain big and important things'. ${ }^{86}$

As Rosenberg points out, Waltz thus warrants the abstraction of the international from the social by referring to the causal determinacy of the anarchical structure of the international environment upon the behaviour of the subject under analysis - states and the patterns of interaction between them. Yet, its weakness is that it may tell us that states will engage in power balancing, but it tells us nothing about the manner in which power is accrued or anything about the manner in which it will be projected.

However, the last decade has witnessed a move by so called neo-classical realists away from highly abstract theorizing. Such writers regard anarchy as a general permissive condition. In so doing, 'Since anarchy and polarity do not determine the actions of states (as acknowledged by structural realists as well), neo-and postclassical realists argue that we need to incorporate other variables as well' ${ }^{\prime}{ }^{87}$ Neo-classical realists still emphasise the importance of the international structure and distribution of power, but they locate 'causal properties at the structural and unit levels, the unit-level factors help to explain state external behavior' ${ }^{88}$

Much of this work chimes with the earlier work of the Structural Realists who made important adjustments to Waltz's Neorealism, some of which this paper seeks to incorporate. First, they make a key distinction between deep structure ('organizational principle plus functional differentiation of units) and distributional structure (systemic patterns in the distribution of unit attributes). Second, they introduce a new system wide concept of interaction capacity. Waltz's assumption that the competitive pressure arising from the anarchical structure will lead to homogeneous units relies on a high level of system-wide interaction capacity to convey the competitive pressures induced by the anarchic environment. If the interaction capacity is sufficiently low, functional differentiation will therefore persist. Moreover, the historical record would seem to indicate that, 'the process of emulation does not necessarily lead to the 
increasing homogenization of political units', rather, it often leads to hybridization of existing and new methods of warfare and production (echoes of UCD here) ${ }^{89}$

This redefinition of the deep structure has important ramifications for the two alternative theories presented in this paper. As is well known, Waltz's version of the international political structure contains three components:: 'the organizing principle of the international system, plus the functional differentiation of units, plus the distribution of capabilities across units'. ${ }^{90}$ But because the competitive pressures generated by the anarchical structure lead to the emergence of like units, functional differentiation drops out and Waltz thus famously asserts that 'international structures vary only through a change of organizing principle or, failing that, through variations in the capabilities of units' ${ }^{91}$ Much of the work by the above two schools has involved the re-introduction of this second component of the international political structure. But within these works there exists two different approaches. The Structural Realists view the functional differentiation of political units as dictating 'the character of the anarchic deep structure of the system', rather than 'simply mediating the deep structural effects of anarchy' as John Ruggie does. ${ }^{92}$ They thus argue that the 'ordering principle of anarchy, has remained unchanged throughout world history. But by incorporating the additional structural component of functional differentiation we are also able to identify that there can be change in the deep structure of the international system'. ${ }^{93}$

For Rosenberg, the latter form of structural realism should appeal. It not only brings in the important variable of interaction capacity, the initial emergence of sub-systems leading to a fully international anarchical structure, but also the functional differentiation of units and its effects on the deep structure of the international system. One could foresee Rosenberg arguing that the emergence of the anarchical order arises from a political multiplicity that originates in the production of surplus. States slowly but surely emerge from this political multiplicity and the form of these states will vary according to the mode of production that pertains within these units. But rather than argue for the continuance of a deep anarchical structure throughout history as Structural Realists do, it could be argued that the very nature of anarchy depends upon what Teschke refers to as the mode of operation of geopolitical orders and this itself is governed by the dominant mode of production within states. ${ }^{94}$

The following argues that an alternative version of Structural Realism to that of melding Structural Realism with Rosenberg's theory, is possible. Such an 
approach is similar to that of Callinicos' in that it argues that the anarchical structure of the international environment does indeed constitute an independent generative structure. Indeed, in the abstract, we can posit at least two trans-historical generative structures throughout most of human development: the internal one of social stratification determined by the various classes' relation to the means of production and the manner in which surplus is accumulated; and the one of anarchy that arises from an international environment populated by independent units in which a supranational authority is absent. ${ }^{95}$ Indeed, if one seeks to follow the mixed mode approach that views both the forces and relations of production as constituting the economic structure of society that pertains in any given epoch, then a trans-historical generative process needs to added - that of technological development.

However, there is a qualitative difference between these two trans-historical generative structures. Social stratification has a multitude of variations depending on the particular classes that pertain at any particular point. Just as Marx's work has been interpreted as identifying various 'trans-historical abstract categories as the foundation for the construction of historically specific categories', one can argue he also identifies a trans-historical generative structure (stratification in terms of the social relations of production) which serves as the foundation for the construction of historically specific class formations associated with a given historical epoch. ${ }^{96}$ Inter-class and intra-class antagonisms (the vertical and horizontal dynamics) and their outcomes will thus vary throughout human development and will depend upon the class configuration and forms of exploitation that attain at the time, the specificity of which can only be acquired through detailed historical analysis.

The anarchical structure, on the other hand, has a binary quality - either the environment is anarchical or a supranational authority exists. As Derek Sayer alerts us, structures can be said to be "'invariant under certain transformations", that is, they can continue to exist while their constituents undergo changes in attributes which are not relevant to their reproduction'. ${ }^{97}$ In this case, state attributes may vary considerably across history but as long as the most relevant attributes of anarchy remain unchanged (absence of a supranational authority in an environment populated by units seeking to survive), then the reproduction of this structure will continue. Here we need to differentiate between this structure and the behaviour it induces. Given the 'unresolvable uncertainty' concerning other states intentions, these units/states, if they wish to survive, must fall back on self-help forms of behaviour thus producing a competitive dynamic into the system whereby they seek to increase their power vis-à-vis other units, 'building 
up their own capabilities (internal balancing) or by aggregating their capabilities with other states in alliances (external balancing) ${ }^{\prime} .{ }^{98}$ The actual manner in which they do so will clearly depend on the mode(s) of production pertaining at that particular point which will be reflected in the mode of inter-state competition at the international level. In other words, it is necessary to differentiate between the anarchical structure and the competitive behaviour it induces and the actual mode(s) of inter-state competition.

Such an approach would thus incorporate the important insight that Benno Teschke makes when he identifies different 'modes of operation of diverse geopolitical orders' that pertain in different historical epochs. ${ }^{99}$ Moreover, his aim to demonstrate, 'how international relations are internally related to politically instituted class relations (social property relations) and how geopolitical pressures affects the course of socio-political development...the economic and the political, the domestic and the international, are never constituted independently of each other' is consonant with this paper. ${ }^{100}$ But, this paper argues that the modes of operation of diverse geopolitical orders, represents the variation in outcomes of state behaviour rather than the anarchical structure per $s e-$ what this paper refers to as the mode of inter-state competition.

In other words, this alternative form of Structural Realism diverges from the original in arguing that the deep structure - the fundamental ordering principles of the international political structure - remains unchanged. Furthermore, this anarchical structure is said to induce competitive self-help behavior for the states/units that populate this environment. However, the form that this competition takes will vary according to the internal composition of these states. The nomenclature 'logics of anarchy' is thus a misnomer derived from an analytical error and this paper argues it should be replaced by 'modes of interstate competition'. However, this alternative approach does incorporate other important insights concerning the interaction capacity of the system as a whole and the variation in state form both temporally, but also variation within the system at any given point in time. Thus, states can vary in terms of their internal mode(s) of production in different historical epochs but also within any give historical epoch. Indeed, articulations and possibly combinations of various modes of production are likely to exist. One may have such variation with the proviso that these political units have in common one key function - that of security provision.

Although, the fundamental ordering principle of the international remains unaltered, the geopolitical behaviour of any given state will, of course, reflect its 
internal composition and the maintenance/transformation of any mode of production will be affected by the geopolitics of the era. Teschke is therefore quite right to argue that 'the economic and the political, the domestic and the international, are never constituted independently of each other' ${ }^{101}$ However, it is important to emphasize that, due to the variation of production forms within any given epoch - one cannot simply deduce from the dominant mode of production the dominant mode of inter-state competition, First, because, as Trotsky points out, curious amalgams of modes of production will emerge within states from the mimetic process induced by inter-state competition. Second, across the system there will often be a variety of dominant modes of production related to different states at any given point. Finally, the interests of the dominant actors associated with a given historical epoch will be refracted through the possibly separate social strata of state elites.

Thus the identification of long term tendencies does not imply constancy in state forms and their internal modes of production across time and space. Nor does this approach have to necessarily fuse with the 'logic of rational choice as a theory of operation' in order to provide an historicized account of international relations. Indeed, Waltz's theory does not make this type of rationality assumption; rather the emphasis is upon an external environment that punishes those states that do not respond to such systemic pressures efficiently. ${ }^{102}$ In Jennifer Sterling-Folker's felicitous phrase, states are 'free to die, but it is the choices they have made vis-àvis themselves and others that determine that outcome, not anarchy itself' ${ }^{103}$ The emphasis is thus on a type of evolutionary game theory rationality which, if states are to survive, are obliged to follow. ${ }^{104}$ So, although Neorealism and the original Structural Realism have little to say about state modalities, one can extrapolate for the current argument that the maintenance or increase in a state's relative power will depend on it adopting the most efficient mode of production that pertains at any given time or indeed a unique amalgam that may sustain its relative power position. Crucially, however, this mimetic process depends on the interaction capacity of the system. If it is high, those states that do not respond to the competitive environment by further power accumulation will find their relative power declining and will suffer the consequences (subordination, conquest or outright annihilation). However, if the interaction capacity is low, depending upon their geographical position, such consequences are not inevitable.

By treating modalities of production and modalities of inter-state competition as inextricably bound together, it may also be possible to solve one of the unresolved debates within the neorealist literature between the 'defensive 
realists' and 'offensive realists' ${ }^{105}$ On the one hand, defensive realists argue that states merely seek the, 'minimum level of power that is needed to attain and to maintain their security and survival'. ${ }^{106}$ On the other hand, offensive realists argue that states 'seek to survive under anarchy by maximizing their power relative to other states, in order to maintain the means for self-defense. Relative power, not absolute levels of power, matters most to states. Thus, states seek opportunities to weaken potential adversaries and improve their relative power position. They sometimes see aggression as the best way to accumulate more power at the expense of rivals'. ${ }^{107}$ Despite starting from the same basic assumptions about the nature of the international environment, these two schools therefore differ in their predictions of state behavior. Yet, if we allow for a range of behaviours depending upon the historical epoch that states find themselves in, it may be possible to overcome this conundrum.

For offensive realists, relative to their power capabilities, states will endeavor as much as possible to control their external environment in order to reduce the possibility of security threats and to maximize the accrual of surplus. (within the confines of any given mode of production). ${ }^{108}$ This version of Neorealism therefore predicts that states will extend their 'sovereignty frontier' as far as their relative capabilities will allow. ${ }^{109}$ Combined with a Marxist analysis, the mode of power exhibited by states both in their method of power accretion internally and the expansion of that power externally can be said to be conditioned by the dominant mode of production within their borders. State elites will thus project state power by extending their 'sovereignty frontier' to the extent that their relative power will allow them, but the form that this extension takes will depend upon the historical epoch under consideration.

For example, the tributary mode of production was inherently expansionary given its dependency on subaltern states transferring part of their wealth on a regular basis to the regional hegemon. And, as Callinicos has already pointed out, under feudalism, the state acted as 'an expanding super-lord whose growing military and fiscal capabilities compensated for the declining extractive powers of individual lords'. ${ }^{110}$ Similarly, the empires of the $19^{\text {th }}$ century sought to extend their sovereignty frontiers through both a mixture of free trade arrangements and the physical possession of overseas territories in order to facilitate the incorporation of these entities into the capitalist mode of production. In part, this reflected the embryonic stage of capitalism and the fact that, in the majority of the world, preceding modes of production predominated and the appropriate economic conditions and the political-legal structure to secure trade were nonexistent. Although the preference may have been for 'trade not rule' the 
conditions that pertained elsewhere necessitated the policy of 'trade with informal control if possible; trade with rule when necessary' ${ }^{111}$ In the absence of appropriate legal regimes at the international level, inter-state competition descended into a scramble for direct territorial control.

In contradistinction, after the Second World War, the US experienced a unipolar moment in which it found itself relatively unchallenged and the majority of the world already integrated into and conditioned by capitalism. As the preponderant power, it was able to promote a sovereign state form across the world that replicated the division of the political and economic spheres that pertained in the vanguard capitalist states. Given the particular form of property relation associated with capitalism, the territorial expansion of states' sovereignty frontiers became redundant. The emphasis thus shifted to the expansion of capitalist property relations through the establishment of a necessary global architecture - the political-legal superstructure required for capitalism to operate smoothly - and the creation of the first truly global empire of civil society. ${ }^{112}$ As a result, state behavior shifted away from power maximization towards securing this global economic architecture in order to maintain the lead states' relative power positions.

However, the creation of this global architecture and its replication of the political and economic divide at the domestic level have not ameliorated the contradictions inherent within the capitalist mode of production - namely competing capitals and the long term decline in the rate of profit. Even during the Second World War, US elites were concerned about a possible post-war slump which would mean 'Unmarketable surpluses of all kinds of goods will accumulate and export markets will be sought to relieve the situation and to stay the decline in the standard of living of our people'. ${ }^{113}$ The European recovery thus served as an important outlet for US spare industrial capacity and capital over accumulation. ${ }^{114}$ Moreover, Europe and Japan were permitted some relative gains in their economic and military power in order to serve as a bulwark against the Soviet Union and China. The inevitable decline in the rate of profit which finally came home to roost in the highly industrialized countries in the late sixties/early seventies led to a further outpouring of capital to those areas that provided far cheaper factors of production. ${ }^{115}$ Thus, uneven and combined development has led to the emergence of alternative centres of power which, although unable, as yet, to individually challenge the US, has led to hegemonic decline and an uncertain future for the global system established after the Second World War. ${ }^{116}$

URL: http:/mc.manuscriptcentral.com/gieh Email: criacis@hermes.cam.ac.uk 


\section{On Methodology}

This paper further suggests that if this alternative Structural Realist approach is to be fused with Marxism a positivist methodology associated with Neorealism should be replaced by a Scientific Realist methodology. This would appear to be closely aligned with Marx's own method. ${ }^{117}$ Essentially, this involves the familiar process of retroduction whereby the researcher attempts to explain identified patterns of occurrences by establishing a hypothetical model regarding the possible generative mechanisms causing such phenomena. ${ }^{118}$ Retroduction thus constitutes a form of 'inference in which events are explained by postulating (and identifying) mechanisms which are capable of producing them'. ${ }^{119}$

Moreover, Scientific Realism rejects the 'positivist limitation of scientific ontology to the observable' ${ }^{120}$ Rather it attempts to explain 'observable phenomena by describing the mechanisms and structures through which various often unobservable entities possess the "power" to generate these occurrences'. ${ }^{121}$ Given the anarchical structure of the international so often referred to is actually not directly observable, this methodology is far better suited to the theoretical challenge than Waltz's positivism (or at least 'hybrid' positivism). ${ }^{122}$ It is also acknowledged that, in the sphere of Social Science, it is unlikely that we will identify certain universal laws and that it is more appropriate to speak of tendencies (an appreciation that one needs to take account of the agential aspect of what is being studied). Yet, the task of the Social Scientist remains that of identifying social regularities and developing hypothetical models that help in understanding the generative mechanisms behind such surface phenomenon. This approach also adopts an iterative methodology because 'Science is seen to proceed through a constant spiral of discovery and understanding, further discovery, and revision, and hopefully more adequate, understanding' ${ }^{123}$

Scientific Realism therefore fits well with the approach argued for in this paper. It is clear that neither Marxism or Structural Realism on their own provides a full account of the causal processes at work in the world system. Both identify different generative mechanisms which explain certain aspects of social change, but once combined they provide a far better explanation of regular patterns of social phenomenon. A fusion of Marxism and the alternative version of Structural Realism presented here should thus be seen as part of the iterative process of scientific investigation that researchers engage in. There are, however, two problems associated with this approach. First, there is a danger that the insights of Structural Realism are simply bolted on to the previous findings of Marxist investigations. But this is not what is recommended here. Of course, the 
generative mechanisms have been identified separately. But, the project at hand must now entail a root and branch re-writing of historical sociological analyses of the various epochs that treats inter-state competition as a necessary constituent element of societal formations/stratification and its reproduction and yet the same time treats modes of production as a major constitutive element of the mode of inter-state competition.

Such a theory identifies certain tendencies based upon the abstract generative structures, but in reality the outcomes may not always chime with our expectations. Thus, 'the challenge is to show historically what constellation of sociopolitical forces struggled at any point in time over the control of the state, to establish which social interests prevailed, and to ascertain how the variable resolution of these conflicts shaped variable national and international strategies of accumulation and territorialization within a multi-state system whose anarchic structure and nationally differentiated development always posed problems of coordination and concertation'. ${ }^{124}$ However, in order to avoid a descent into 'historical inductivism', such resolutions of conflicts need to be constantly compared to the outcome one would expect given the mode(s) of inter-state competition and the mode(s) of production pertaining to the period under consideration and to provide further explanation if these resolutions differ to the expected outcome. ${ }^{125}$ In other words, it is highly likely that the effects of these two generative structures will be mediated by other generative structures/mechanisms (state institutions for example) which then need to be taken into account. Such an iterative process will move the research further from the abstract to the concrete.

If such complexities are to be captured, rather than simply adopt a highly abstract form of theorizing (the necessary abstraction from the concrete), uneven and combined development should also be applied to detailed historical explications of its various phases: genesis, structure, epochs and conjunctures (the necessary shift from the abstract to the concrete). Such analysis would adopt an open sociological framework informed by Marxian analysis, one that would acknowledge 'the inherent complexity and contingency (or open-endedness) of processes of change in which human subjects are involved'. ${ }^{126}$ Such research should endeavour to fully encompass the concatenation of causal factors operating within a given period that have led to the identified outcome. Little of this complexity will be captured at the level of abstraction and there is the danger that if UCD is 'extirpated from capitalism and projected into the stratospheric heights of the international...it will tend to lose it explanatory edge, acquiring the disabling aura of banality' ${ }^{127}$ In order to avoid such an outcome, 
this paper has argued that one must temporally slice the history of development not only into phases of genesis and structure for each mode of production but further into historical epochs and conjunctures. The mutable nature of uneven and combined development that is ultimately dependent upon the mode of production and inter-state competition renders high levels of abstraction rather unproductive, the suggested solution has the benefit of providing focus to an otherwise overly generalized and sweeping view of the historical process.

The second issue is whether Structural Realism can be altered in such a fashion. This paper argues in the positive for such a change. In so doing, such an approach would avoid the methodological weaknesses of positivism associated with Neorealism and recognize the crucial effect states' modes of production have on the modes of inter-state competition for any given historical epoch and vice versa. Indeed, as mentioned earlier, Waltz has never quite explained how, if he is really adopting a positivist approach, the central generative mechanism anarchy - is an unobservable entity, something that would be easier to incorporate into the methodological approach of Scientific Realism. Moreover, the general theoretical abstractions avoid the charge of inductivism, while the iterative process of contrasting expected outcomes with historical record and introducing further specificity to the theoretical model where required, avoids the charge of abstracting to the point of producing a 'disabling aura of banality' ${ }^{128}$

\section{Conclusion}

Rosenberg is seeking to fulfill several objectives with his version of uneven and combined development: a better historical materialist account of the international than that put forward by Callinicos; a better account of international relations than Neorealism; and finally to actually explain the emergence of the international rather than treating multiplicity as a given social fact. In relation to the latter, Rosenberg makes a distinction between social multiplicity and political multiplicity.

However, this paper has argued that the central characteristic of the international constituting the core problematique for International Relations scholars is the anarchic environment in which states/societies reside and that the emergence of such a condition precedes political multiplicity. As such, Rosenberg's emphasis upon the emergence of social stratification is unwarranted. Instead, this paper has argued for a general theory of societal evolution that does not absent the international from its analysis, but takes it into account through the positing of

URL: http:/mc.manuscriptcentral.com/gieh Email: criacis@hermes.cam.ac.uk 
two trans-historical generative structures: social stratification and anarchy. From these two social structures, the inextricable intertwining of various modes of production and modes of inter-state competition are derived. In so doing, an alternative form of Structural Realism was suggested - one that could be fused with Marxism to provide an abstract theoretical basis for uneven and combined development.

But such a fusion only represents the beginning of a root and branch revision of historical sociology. One that does not treat these modes of production and modes of inter-state competition as somehow constituted separately. Further, the complex process of uneven and combined development requires a detailed breakdown into: the genesis and structural phases of the various modes of production/inter-state competition; and then to further divide this into distinctive epochs during the lifetime of various modes of production; and, finally, focusing on determinate historical moments. ${ }^{129}$ Such investigation must be an iterative process of increasingly deeper analysis that may identify additional factors that need to be incorporated. 
1 The author would like to thank the anonymous reviewers for their insightful comments that have (hopefully) led to a much improved paper. My thanks also extend to Ben Selwyn for re-kindling my interest in these topics. Last but certainly not least, my thanks to Jamie Allinson who has provided constant advice on the subject, alongside copious amounts of literature that have helped consolidate my thoughts on the issue. Needless to say, I take full responsibility for the orrery of errors that follows.

2 Gonzalo Pozo-Martin, 'Autonomous or materialist geopolitics?', Cambridge Review of International Affairs 20:4, 2007, p. 554.

3 This of course has very similar undertones to 'The Two Logics' approach. However, this approach emphasizes a division between the actual anarchical structure (which has a binary form unlike social stratification) and the modes of international competition that actually arise from the competition induced by this structure and the modes of production that pertain at that point in time. Moreover, it posits a common methodology for these two approaches which will facilitate a true melding of the two. Giovanni Arrighi, 'Hegemony Unravelled - Part 1', New Left Review 32, 2005, pp. 23-80; Giovanni Arrighi, 'Hegemony Unravelled - Part 2', New Left Review 33, 2005, pp. 83-116 4 Alex Callinicos, 'Epoch and Conjuncture in Marxist Political Economy', International Politics, 42:3, 2005, p. 362.

5 In the following, RUCD refers to both RUCD I and II. RUCD II refers to Justin Rosenberg, 'Basic problems in the Theory of Uneven and Combined Development, part II: unevenness and political multiplicity', Cambridge Review of International Affairs, 23:1, March 2010, pp. 165-89. Whereas RUCD I refers to not only his discussion in CRIA but also other earlier pieces. In other words: Justin Rosenberg, 'Basic problems in the theory of uneven and combined development: a reply to the CRIA forum', Cambridge Review of International Affairs 22:1, 2009, pp. 107-110; Alex Callinicos and Justin Rosenberg, 'Uneven and combined development: the social-relational substratum of the international? An exchange of letters', Cambridge Review of International Affairs 221:1, 2008, pp. 77-112; Justin Rosenberg, 'Why is There No International Historical Sociology?', European Journal of International Relations 12:3, pp. 307-40; Justin Rosenberg, 'Globalization Theory: A Post Mortem', International Politics 42, 2005, pp. 2-75; Justin Rosenberg, 'Anarchy in the Mirror of 'Uneven and Combined Development', BritishGerman International Relations Conference, May 2008, pp. 1-31.

${ }^{6}$ Alex Callinicos, 'Epoch and Conjuncture', p. 355.

${ }^{7}$ Alex Callinicos and Justin Rosenberg, 'Uneven and combined development: the socialrelational substratum of the international? An exchange of letters', Cambridge Review of International Affairs 221:1, 2008, p. 84 (pp. 77-112).

8 Giovanni Arrighi, The Long Twentieth Century: Money, Power, and the Origins of Our Times. London: Verso, 1994, p. 34; Giovanni Arrighi, 'Hegemony Unravelled - Part 1', New Left Review 32, 2005, pp. 23-80; Giovanni Arrighi, 'Hegemony Unravelled - Part 2', New Left Review 33, 2005, pp. 83-116; David Harvey, The New Imperialism Oxford: Oxford University Press, 2003; Alex Callinicos, The New Mandarins Of American Power 
Cambridge: Polity Press, 2003; Alex Callinicos, Imperialism And Global Political Economy Cambridge: Polity Press, 2009.

${ }^{9}$ Alex Callinicos, 'Uneven and combined development: the social-relational substratum of the international?', p. 91 Callinicos argues that the 'whole point of Marx's method of the progressive non-deductive introduction of ever more concrete determinations is to integrate all the relevant empirical content in an articulated structure'. Alex Callinicos, 'How to solve the many-state problem: a reply to the debate', Cambridge Review of International Affairs, 22:1, 2009, p. 98 (89-105).

10 Alex Callinicos, 'How to solve the many-state problem: a reply to the debate', p. 98.

11 On the relationality of capital, refer to Alex Callinicos, Imperialsim And Global Political Economy Cambridge: Cambridge University Press, 2009, p. 12.

12 Alex Callinicos, 'Marxism and the International', British Journal of Politics and International Relations, 6, 2004, p. 432.

13 Alex Callinicos, 'Marxism and the International', p. 432.

14 Justin Rosenberg, 'Uneven and combined development: the social-relational substratum of the international?, p. 79-80. However, there is an issue here as to whether the actual historical variation in forms of political multiplicity led to qualitatively different forms of anarchy to that in which sovereign states constitute populate the system. See later argument

15 Justin Rosenberg, 'Uneven and combined development: the social-relational substratum of the international?', p. 87.

16 Justin Rosenberg, 'Uneven and combined development: the social-relational substratum of the international?', p. 78

17 Justin Rosenberg, 'Uneven and combined development: the social-relational substratum of the international?', p. 92.

18 Karl Marx, Capital Volume 1, Harmondsworth : Penguin Books, 1976, pp.168-9.

19 Marx defines socially necessary labour-time as 'the labour-time required to produce any use-value under the conditions of production normal for a given society and with the average degree of skill and intensity of labour prevalent in that society'. Karl Marx, Capital Volume 1, pp. 129-30.

20 Karl Marx, Capital Volume 1, p. 168.

21 Justin Rosenberg, 'Uneven and combined development: the social-relational substratum of the international?', p. 80.

22 Justin Rosenberg, 'Uneven and combined development: the social-relational substratum of the international?', p. 94.

23 Justin Rosenberg, 'Uneven and combined development: the social-relational substratum of the international? , p. 88. Parentheses added

24 Leon Trotsky, The History of the Russian Revolution. Available. Online at $<$ www.marxists.or/archive /trotsky/1930/hrr/ch01.htm>, Accessed 22 March 2010, p. 2.

${ }^{25}$ Leon Trotsky, The History of the Russian Revolution. pp. 2-3. 
26 Leon Trotsky, The History of the Russian Revolution. Available. Online at $<$ www.marxists.or/archive /trotsky/1930/hrr/ch01.htm>, p. 2.

27 On the fusing of old and new structures, refer to Justin Rosenberg, 'Isaac Deutscher and the Lost History of International Relations', New Left Review, 1:215, p. 8. (3-15).

${ }^{28}$ Justin Rosenberg, 'Globalization Theory: A Post Mortem', International Politics 42:1, pp. 40-1 (2-74).

${ }^{29} \mathrm{Alex}$ Callinicos and Justin Rosenberg, 'Uneven and combined development: the socialrelational substratum of the international? An exchange of letters', Cambridge Review of International Affairs 221:1, 2008, p. 86.

30 Jamie Allinson and Alexander Anievas, "The uses and misuses of uneven and combined development: an anatomy of a concept', Cambridge Review of International Affairs, 22:1, 2009, p. 54. (47-67)

${ }^{31}$ Alex Callanicos and Justin Rosenberg, 'Uneven and combined development: the social-relational substratum of the international? An exchange of letters', Cambridge Review of International Affairs 221:1, 2008, pp. 94-5.

32 Leon Trotsky, The History of the Russian Revolution. Available. Online at $<$ www.marxists.or/archive /trotsky/1930/hrr/ch01.htm>, pp. 2-3.

${ }^{33}$ Jamie Allinson and Alexander Anievas, 'The uses and misuses', p. 51.

${ }^{34}$ For more on this, refer to Jamie Allinson and Alexander Anievas, 'The uses and misuses', p. 63.

${ }^{35}$ Jamie Allinson and Alexander Anievas, 'The uses and misuses', p. 54.

${ }^{36}$ Justin Rosenberg, 'Basic problems in the theory of uneven and combined development, part II: unevenness and political multiplicity', 23:1, March 2010, p. 180

${ }^{37}$ Justin Rosenberg, 'Basic problems', p. 180.

${ }^{38}$ Justin Rosenberg, 'Basic problems', p. 183.

${ }^{39}$ Justin Rosenberg, 'Basic problems', p. 18. The passage in double quotes, Rosenberg has taken from Barry Buzan and Richard Little, International Systems in World History: remaking the study of international relations, Oxford: Oxford University Press, 2000, p. 183. ${ }^{40}$ Justin Rosenberg, 'Basic problems', p. 185.

${ }^{41}$ Jamie Allinson and Alexander Anievas, 'The uses and misuses of uneven and combined development: an anatomy of a concept', Cambridge Review of International Affairs, 22:1, 2009, p. 54. (47-67)

${ }^{42}$ Jamie C. Allinson and Alexander Anievas, 'Approaching 'The International': Beyond Political Marxism', Marxism and World Politics: Contesting Global Capitalism, (London:

Routledge, 2010), p. 212.

${ }^{43}$ Shlomo Avineri, The Social and Political thought of Karl Marx, (Cambridge, Cambridge University Press, 1968), p. 71. See also Alex Callinicos' chapter "Marx's Method", The Revolutionary Ideas of Karl Marx, (London, Bookmarks, 1983).

${ }^{44}$ Marx and Engels, The German Ideology, op. cit., p. 18. 
${ }^{45}$ This definition of productive forces is taken from G. Cohen, Karl Marx's Theory of History: A Defence, Oxford, Oxford University Press, 1978, p. 32 in which labour power includes strength, skill, knowledge inventiveness etc.

${ }^{46}$ Karl Marx, Preface And Introduction To A Contribution To The Critique Of Political Economy, (Peking, Foreign Languages Press, 1976), p. 3.

${ }^{47}$ G. Cohen, op. cit., p. 134. Trotsky warned against this form of determinism particularly in relation to the role of the proletariat during the Russian Revolution - 'To imagine that the dictatorship of the proletariat is in some way automatically dependent on the technical development and resources of a country is a prejudice of "economic" materialism simplified to absurdity'. Refer to Leon Trotsky, Results and Prospects, Chapter IV 'Revolution and the Proletariat'. Available. Online at $<$ http://www.marxists.org/archive/trotsky/1931/tpr/rp04.html>. Accessed 22 March 2010, p. 2.

${ }^{48}$ G. Cohen, op. cit., p. 160.

49. See for example Alex Callinicos, Is There A Future For Marxism?, (London, MacMillan, 1982) p. ix and p. 147.

50 . Refer to Paul Blackledge's account of 'Political Marxism' in Jaques Bidet and Stathis Kouverlakis, Critical Companion To Contemporary Marxism, Chicago: Haymarket Books, 2009, pp. 267-284. See also Ellen Meiksins Wood, The Origin of Capitalism: a longer view, London: Verso, 2002; Robert Brenner, 'Agrarian Class Structure and Economic Development in Pre-Industrial Europe, Past E Present, 70, 1976, pp. 30-75; and Robert Brenner, 'The Agrarian Roots of European Capitalism', Past E Present, 97, 1982, pp. 16113. Hannes Lacher, Beyond Globalization, p. 68.

51 Maurice Dobb, 'A Reply" in Rodney Hilton, The Tranisition from Feudalism to Capitalism, London: Lowe \& Brydone, 1976, p. 59.. See also Maurice Dobb, Studies In The Development of Capitalism London: Routledge \& Kegan Paul, 1946.

52 Robert Brenner, 'Agrarian Class Structure and Economic Development' in T.H. Aston and C.H.E. Philpin (eds), The Brenner Debate: Agrarian Class Structure and Economic Development in Pre-Industrial Europe, Cambridge: Cambridge University Press, 1987, p. 49. ${ }^{53}$ Paul Sweezy, 'A Critique" in Rodney Hilton, The Tranisition from Feudalism to Capitalism, London: Lowe \& Brydone, 1976, p. 42

${ }^{54}$ Chris Harman in Chris Harman and Robert Brenner, 'The Origins of Capitalism'. Discussion organized by International Socialism and Historical Materialsim in November 2003. Available. Online at <http://www.marxists.org/archive/harman/2008/xx/ wickham.html $>$. Accessed 22 March 2010.

55 Jon Elster, 'Theory of combined and uneven development' in John Roemer (ed), Analytical Marxism, Cambridge: Cambridge University Press, 1986, p. 56.

56 Perry Anderson, Lineages Of The Absolutist State, London: Verso, 1984, p. 417.

${ }^{57}$ Refer to Jacques Bidet, Exploring Marx's Capital: Philosophical., Economic and Political Dimensions, Leiden: BRIL, 2007, pp. 172-3.

58 Perry Anderson, Lineages Of The Absolutist State, p. 417.

59 On the crisis of accumulation and spatio-temporal fixes refer to David Harvey, The New Imperialism. Oxford: Oxford University Press, 2003; David Harvey, Limits to Capital, 
London: Verso, 2006; David Harvey, Spaces of Global Capitalism: Towards a theory of uneven geographical development, London: Verso, 2006.

${ }^{60}$ It should be noted that the paper is not referring to his earlier work here, such as, Justin Rosenberg, The Empire of Civil Society: Critique of the Realist Theory of International Relations、London: Verso, 1994.

${ }^{61}$ Alex Callinicos, 'Epoch and Conjuncture', p. 355.

${ }^{62}$ Alex Callinicos, 'Epoch and Conjuncture in Marxist Political Economy', International Politics, 42, 2005, p. 355.

${ }^{63}$ Perry Anderson, Lineages Of The Absolutist State, London: Verso, 1984, pp. 421-3.

${ }^{64}$ The dead seize the living. As Marx pointed out in the preface to Capital, 'In all other spheres, we, like all the rest of Continental Western Europe, suffer not only from the development of capitalist production, but also from the incompleteness of that development. Alongside the modern evils, a whole series of inherited evils oppress us, arising from the passive survival of antiquated modes of production, with their inevitable train of social and political anachronisms. We suffer not only from the living, but from the dead'. Refer to, Karl Marx, Capital Volume One, 1867-Preface to the First German Edition, Chicago: Charles H Kerr \& Company, 1909, p. 13. Cited in Hannes Lacher, Beyond Globalization: Capitalism, Territoriality and the International Relations of Modernity, London: Routledge, 2007, p. 42.

65 Justin Rosenberg, 'Basic problems', p. 182.

${ }^{66}$ It is thought that such areas of abundance began to appear in the post- glacial or Holocene period. Barry Buzan and Richard Little, International Systems in World History: remaking the study of international relations, Oxford: Oxford University Press, 2000, p. 136.

${ }_{67}$ 'When communities become sedentary, the population starts to rise. One explanation for this is the reduced transportation demands on women'. Barry Buzan and Richard Little, International Systems in World History, p. 139.

68 Barry Buzan and Richard Little, International Systems in World History, p. 158.

69 Barry Buzan and Richard Little, International Systems in World History, p. 123.

70 Some support for this can be seen in some South American tribes where the primary aim of raids is 'killing as many of the enemy as possible together with a secondary aim of looting'. Barry Buzan and Richard Little, International Systems in World History, p. 144.

${ }^{71}$ Karl Marx, Grundrisse, (1857-8), London, Penguin Books Ltd., 1973, p. 472.

72. 'Forms which precede capitalist production' in the Grundrisse, 1973, pp. 471-479.

73 Karl Marx, Grundrisse, p. 491.

${ }_{74}$ Karl Marx, Grundrisse, p. 493-4. Bold Font added.

${ }^{75}$ Nicholas Wheeler and Ken Booth, 'The Security Dilemma', in John Baylis and Nicholas Rengger (eds.), Dilemmas of World Politics. International Issues in a Changing World, Oxford: OUP, 1992, p. 34.

76 Kenneth Waltz, Theory of International Politics, New York: McGraw-Hill, 1979, p.121. Although Buzan and Little disagree with this possibility because of the fragility of these units, it is clear that whether some units disappear or not, the generalized state of anarchy remains. Barry Buzan and Richard Little, International Systems in World History: remaking the study of international relations, Oxford: Oxford University Press, 2000, p. 158 
77 Barry Buzan, Charles Jones and Richard Little, The Logic Of Anarchy: Neorealism to Structural Realism, New York: Columbia University Press, 1993, p.77.

78 Barry Buzan, Charles Jones and Richard Little, The Logic Of Anarchy, p. 79. I would suggest at a much earlier stage than these authors do, particularly in relation to the system consequences of the mutual recognition of the Chinese and Roman empires. Refer to p. 94.

${ }^{79}$ Michael Mann, 'The Autonomous Power of the State', in John Hall (ed.), States in History, Oxford: Basil Blackwell, 1986, pp. 113-116

${ }^{80}$ Email correspondence with Jamie Allinson, 25 February 2011.

${ }^{81}$ Barry Buzan and Richard Little, International Systems in World History, p. 135.

82 Justin Rosenberg, 'Basic problems', p. 185.

83 Jack Donnelly, Realism and International Relations, Cambridge University Press, Cambridge, 2000, p. 107.

84 Ibid., p. 115.

85 Ibid., p. 27.

86 Kenneth Waltz, 'Interview with Ken Waltz', Review of International Studies, 24:3, 1998, p. 384

87 Anders Wivel, 'Explaining why state $X$ made a certain move last Tuesday: The promise and limitations of realist foreign policy analysis', Journal of International Relations and Development 8, p. 357.

${ }^{88}$ Jeffrey Taliaferro, Steven Lobell and Norrin Ripsman, 'Neoclassical Realism, the State, and Foreign Policy', in Jeffrey Taliaferro, Steven Lobell and Norrin Ripsman, Neoclassical Realism, the State, and Foreign Policy, Cambridge: Cambridge University Press, 2011) p. 19.

89 Barry Buzan, Charles Jones and Richard Little, The Logic Of Anarchy, p. 127.

90 Barry Buzan, Charles Jones and Richard Little, The Logic Of Anarchy, p. 36.

91 Kenneth Waltz, Theory of International Politics, p. 93.

92 Barry Buzan, Charles Jones and Richard Little, The Logic Of Anarchy, p. 88 and John Ruggie, 'Continuity and Transformation in the World Polity: Towards a Neorealist Synthesis', in Robert Keohane (ed.), Neorealism and its Critics, (New York: Columbia University Press, 1986), p. 135 and John Ruggie, 'Continuity and Transformation in the World Polity: Towards a Neorealist Synthesis', World Politics, 35: 2 (Jan., 1983), pp. 261285.

93 Barry Buzan, Charles Jones and Richard Little, The Logic Of Anarchy, p. 88

94 Benno Teschke, The Myth of 1648, p. 7.

95 Trans-historical up to this point in time - but not making any prediction for the future of these structures - i.e. it does not rule out the possibility of a classless society or a global polity - however unlikely both seem.

${ }_{96}$ Joseph Fracchia, 'On Transhistorical Abstractions and the Intersection of Historical Theory and Social Critique', Historical Materialism, 12:3 2004, p. 128.

${ }^{97}$ Derek Sayer, Method in Social Science: Second Edition, London: Routledge, 2010, p. 94.

${ }^{98}$ Stephen Brooks and William Wohlforth. 'Hard Times for Soft Balancing'. International Security 30, 2005, pp. 76-7 
99 Benno Teschke, The Myth Of 1648: Class, Geopolitics and the Making of Modern International Relations, London: Verso, 2003, p. 7.. See also Benno Teschke, ' Geopolitical Relations in the European Middle Ages: History and Theory', International Organization, 52:2, 1998, pp. 325-358 For a similar approach, refer to Hannes Lacher, Beyond Globalization: Capitalism, Territoriality and the International Relations of Modernity, London: Routledge, 2007.

100 Benno Teschke, The Myth Of 1648, p. 272.

101 Benno Teschke, The Myth Of 1648, p. 272.

102 Benno Teschke, The Myth of 1648: Class, Geopolitics and the Making of Modern International Relations, London: Verso, 2003, pp. 42 \&271. Teschke emphasizes Robert Gilpin's endeavours in this area. In addition Lacher argues that 'The classic anarchy probelmatique Of IR (i.e. the explication of the rational forms of action and the resultant repetitive patterns of interaction that are said to prevail where no overarching political authority exists) has received diverse renditions'. Refer to Hannes Lacher, Beyond Globalization, p. 30. However, in the Theory of International Politics, Waltz explicitly states that, 'the theory requires no assumptions of rationality or of constancy of will on the part of all of the actors', p. 118 and 'Anarchic Orders and Balances of Power' in Robert Keohane (ed.), Neorealism and its Critics, New York: Columbia University Press, 1986, p. $11 \&$ (98-131). There are others that do assume rational behaviour. Refer to Joseph Grieco, 'Realist International Theory and the Study of World Politics', in Michael Doyle and John Ikenberry, New Thinking in International Relations Theory, Boulder, Colorado: Westview Press, 1997, p. 165; Joseph Gieco, 'State Interests and Institutional Rule Trajectories: A Neorealist Interpretation of the Maastricht Treaty and European Economic and Monetary Union', Security Studies, vol. 5:3, P. p. 282; Dale Copeland, 'Theory and History in the Study of Major War', Security Studies, 10:4, 2001, p. 214 (21239) and The Origins of Major War, Ithaca: Cornell University Press, 2000; John Mearsheimer, The Tragedy of Great Power Politics, New York: W.W. Norton \& Company, 2001, p. 31.

${ }^{103}$ Jennifer Sterling-Folker, 'Realist Environment, Liberal Process, and Domestic-Level Variables', International Studies Quarterly 41, 1997, p. 19. Quoted in Brian Rathburn, 'A Rose By Any Other Name: Neoclassical Realism as the Logical and Necessary Extension' of Structural Realism, Security Studies 17, 2008, p. 311

${ }^{104}$ Email correspondence with Jamie Allinson, 25 February 2011

105 Jack Snyder, Myths of Empire: Domestic Politics and International Ambition, Ithaca. New York: Cornell University Press, 1991, pp. 11-12; Joseph Grieco, 'Realist International Theory and the Study of World Politics'; Jack Donnelly, Realism and International Relations, p. 53.

106 Joseph Grieco, 'Realist International Theory and the Study of World Politics', p. 167. See also his, 'Anarchy and the Limits of Cooperation: A Realist Critique of the Newest Liberal Institutionalism', International Organization, 42:3, 1988, pp. 485-508; and 'Anarchy and the Limits of Cooperation: A Realist Critique of the Newest Liberal Institutionalism', 
in David Baldwin (ed.), Neo-realism and NeoLiberalism, New York: Columbia University Press, 1993, pp. 116-42.

107 John J. Mearsheimer, 'Back to the Future: Instability in Europe after the Cold War', International Security, 15:1, 1990, p. 11. See also Mearsheimer, The Tragedy of Great Power Politics, New York: W. W. Norton and Company, 2001 in which he reiterates that states seek to maximise their power and strive to become regional hegemons, but also adds that states sometimes refrain from increasing their military power further because 'they recognize that doing so would not give them a strategic advantage over their rivals', pp.. 33-6 \& 76. See also Jennifer M. Lind, 'Pacifism or Passing the Buck? Testing Theories of Japan's Security Policy,' International Security, 29:1 2004, p. 103.

108 Jack Snyder, Myths of Empire, pp. 11-12; Jack Donnelly, Realism and International Relations, Cambridge: Cambridge University Press, 2000, p. 53.

109 Graham Harrison, The World Bank and Africa: The Construction of Governance States. London: Routledge, 2004; and Mark Duffield, Development, Security And Unending War: Governing The World Of Peoples Cambridge: Polity Press, 2007, p. 166. This term is used extremely loosely here and is not intended to imply sovereignty as a concept and empirical has existed throughout the history of states. Simply, it is a convenient way of expressing a state's control of its external environment.

110 Alex Callinicos, 'Uneven and combined development: the social-relational substratum of the international? An exchange of letters', Cambridge Review of International Affairs 22:1, 2008 , p. 101. Although there is some discussion as to whether the tributary and feudal modes of production can be clearly separated. Refer to John Haldon, The State and the Tibutary Mode of Production. London: Verso, 1993, Chapter Three.

${ }^{111}$ For example, see John Gallagher and Ronald Robinson, 'The Imperialism of Free Trade', The Economic History Review, New Series, 6: 1, (1953), p. 13.

112 Justin Rosenberg, The Empire of Civil Society

${ }^{113}$ Harry Hawkins, Chief of the Division of Commercial Policy in a memorandum responding to Keynes' desire for the maintenance of Britain's imperial preferences. Patrick Hearden, Architects of Globalism: Building a New World Order during World War II, Arkansas: University of Arkansas Press, 2002, p. 31.

114 As Ellen Meiksins Wood points out, the goal was to open other economies, their resources, their labour and their markets, to western, and especially US capital. This was to be accomplished by the simple means of making the reconstruction of European economies and the development of the 'third world dependent on their compliance with conditions imposed in the main by the US'. Refer to Empire of Capital, London: Verso, 2003, p. 132.

115 Robert Brenner, The Economics Of Global Turbulence: The Advanced Capitalist Economies from Long Boom to Long Downturn, 1945-2005. London: Verso, 2006, pp.143-229; Alex Callinicos, 'Does capitalism need the state system?' Cambridge Review of International Affairs, 20:4, 2007, pp. 533-49;; David Harvey, The New Imperialism Oxford: Oxford University Press, 2003; David Harvey, Spaces of Global Capitalism: Towards a theory of 
Uneven Geographical Development. London: Verso; Peter Gowan, The Global Gamble: Washington's Faustian Bid for World Dominance London: Verso, 1999.

116 Alex Callinicos, Imperialism and Global Political Economy. Cambridge: Polity Press, 2009.

117 Derek Sayer, Method in Social Science.

118 Norman Blaikie, Approaches to Social Inquiry, Cambridge : Polity Press, 1993.

119 Derek Sayer, Method in Social Sciene, p.143.

120 Russell Keat and John Urry, Social Theory As Science, London: Routledge and Kegan Paul, 1975, p.231

121 Russell Keat and John Urry, Social Theory, p.232; See also Roy Bhaskar, A Realist Theory of Science, Sussex: Jarvester Press Ltd., 1978.

${ }_{122}$ On Waltz's rather eclectic approach, refer to Charles Jones' excellent deconstruction in Barry Buzan, Charles Jones and Richard Little, The Logic Of Anarchy, pp. 186-97.

${ }^{123}$ Heikki Patomaki and Colin Wight, 'After Postpositivism? The Promises of Critical Realism' International Studies Quarterly, 44:2, 2000, p.224. See also the special issue of on Scientific Realism in Millennium, 35:2, 2007, particularly Colin Wight, 'A Manifesto for Scientific Realism in IR: Assuming the Can-Opener Won't Work!', Millennium: Journal of International Studies, 35:2, 2007, pp. 379-98.

124 Benno Teschke and Hannes Lacher, 'The changing "logics” of capitalist competition', Cambridge Review of International Affairs 20:4, 2007, p. 570.

125 Alex Callinicos, 'How to solve the many-state problem: a reply to the debate', Cambridge Review of International Affairs 22:1, 2009, p. 98.

${ }^{126}$ Colin Hay, Poltical Analysis: A Critical Introduction, Basingstoke: Palgrave, 2002, p. 48.

${ }_{127}$ Gonzalo Pozo-Martin, 'Autonomous or materialist geopolitics?', Cambridge Review of International Affairs 20:4, 2007, p. 556.

${ }^{128}$ Gonzalo Pozo-Martin, 'Autonomous or materialist geopolitics?', p. 556.

129 Alex Callinicos, 'Epoch and Conjuncture', p. 355. 